\title{
Optimization of Centralized Procurement Process in Military Academies
}

\author{
Yu Bin ${ }^{1,2}$, Liu Baoping ${ }^{1}$, and Kang Weijia ${ }^{1,3^{*}}$ \\ ${ }^{1}$ Naval University of Engineering, Wuhan 430033, Hubei \\ ${ }^{2}$ Unit 31423 of the Chinese People's Liberation Army, Shenyang 110000, Liaoning \\ ${ }^{3}$ Unit 32680 of the Chinese People's Liberation Army, Shenyang 110000, Liaoning
}

\begin{abstract}
Military academies, as military talent training and national defense technology independent innovation bases, is an important issue for military academies to establish a set of procurement management processes, so as to continuously promote the improvement of military academies' procurement support construction level. Based on the main contradictions and problems in the current centralized procurement process of military academies, this article optimizes the centralized procurement process, hoping to make the centralized procurement process of military academies more standardized, efficient and fairer.
\end{abstract}

\section{Introduction}

At the 2015 Military Commission Reform Work Conference, Comrade Xi Jinping pointed out that "we must advance the military management revolution with efficiency as the core, and continuously improve the military's professional refined and scientific management level." [1]. As an important part of military procurement, the procurement of military academies is a bridge and link connecting the battlefield and the market. The procurement of academies plays an important role in supporting the school's teaching, scientific research, training and other related work [2]. Currently, the Military Commission's support for military academies is continuously increasing, and procurement tasks are constantly increasing. The procurement of military academies is faced with the characteristics of large amount, variety, and strong professionalism, which puts forward higher requirements on the quality and efficiency of military academies' procurement.

\section{The basic situation and problems of the current process of centralized procurement in military academies}

\subsection{The current centralized procurement business process}

With the gradual advancement of the reform of the military procurement system, the current military academies have basically achieved centralized procurement of procurement items above the quota. According to the procurement policies and regulations of the Logistics Support Department of the Military Commission, in accordance with relevant requirements, combined with the situation of various institutions, the current procurement process of military academies can be roughly divided into six stages: processing project approval; procurement requirements review and reporting (release); organization and implementation ; Signing the contract; quality inspection, receipt and payment settlement; handling of doubts and complaints and file management.

\subsection{Some problems in the current centralized procurement process}

Due to the particularity of military academies' procurement and the characteristics of the academy's own establishment system, there are still some problems in the centralized procurement process. A centralized procurement process compatible with the centralized procurement of military academies is required to ensure that the military academies are centralized. Procurement work is standardized, scientific, rigorous and practical[3]. In order to more accurately summarize the current situation of centralized procurement management in military academies, a questionnaire was issued to sort out the situation.

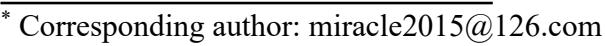


Table 1. Research on the current situation of centralized procurement process in Military Academies

\begin{tabular}{|c|c|c|}
\hline NO. & PROBLEM & OPTIONS \\
\hline 1 & Does the school have an independent purchasing agency? & $\begin{aligned} \text { 1.YES }(72) \\
\text { 2.NO }(0)\end{aligned}$ \\
\hline 2 & $\begin{array}{l}\text { Has the school formulated regulations for centralized procurement } \\
\text { management? }\end{array}$ & $\begin{aligned} \text { 1.YES }(72) \\
\text { 2.NO }(0)\end{aligned}$ \\
\hline 3 & Is the school's centralized procurement process clear? & $\begin{aligned} \text { 1.YES }(72) \\
\text { 2.NO }(0)\end{aligned}$ \\
\hline 4 & Does the school have its own procurement platform? & $\begin{array}{l}\text { 1.YES }(32) \\
\text { 2.NO }(28) \\
\text { 3. Not sure }(12)\end{array}$ \\
\hline 5 & $\begin{array}{l}\text { Does the school's purchasing management department have full-time } \\
\text { purchasing assistants? }\end{array}$ & $\begin{array}{c}\text { 1.NO (0) } \\
\text { 2.YES (1-2) (52) } \\
\text { 3.YES (2-3) (16) } \\
\text { 4. Not sure (4) }\end{array}$ \\
\hline 6 & Is there an electronic filing of the school's procurement files? & $\begin{array}{l}\text { 1.YES (36) } \\
\text { 2.NO (24) } \\
\text { 3. Not sure (12) }\end{array}$ \\
\hline 7 & Has the school organized procurement business training? & $\begin{array}{l}\text { 1.YES (56) } \\
\text { 2.NO (8) } \\
\text { 3. Not sure }(8)\end{array}$ \\
\hline 8 & $\begin{array}{c}\text { During the procurement process, do you feel that the communication } \\
\text { between the various departments is smooth? }\end{array}$ & $\begin{array}{l}\text { 1.YES }(48) \\
\text { 2.NO }(16)\end{array}$ \\
\hline 9 & Has the school established a leading group for school procurement? & $\begin{array}{l}\text { 1.YES }(40) \\
\text { 2.NO }(16) \\
\text { 3. Not sure }(16)\end{array}$ \\
\hline 10 & $\begin{array}{l}\text { How many days did it take for the school's recently completed } \\
\text { bidding procurement project of more than } 1 \text { million yuan? (Report to } \\
\text { contract signing) }\end{array}$ & $\begin{array}{l}1.90(44) \\
2.90-120(16) \\
3.120(4) \\
\text { 4. Not sure (8) }\end{array}$ \\
\hline 11 & $\begin{array}{l}\text { How many days did the school's recently completed bidding and } \\
\text { procurement projects of more than } 5 \text { million yuan take? (Report to } \\
\text { contract signing) }\end{array}$ & $\begin{array}{c}1.90(8) \\
2.90-120(12) \\
3.120(24) \\
\text { 4. Not sure (28) }\end{array}$ \\
\hline 12 & $\begin{array}{l}\text { Do you understand the procurement process of emergency } \\
\text { procurement projects? }\end{array}$ & $\begin{array}{l}\text { 1.YES }(28) \\
\text { 2. Not sure }(20) \\
\text { 3.A little }(24)\end{array}$ \\
\hline 13 & $\begin{array}{l}\text { Is the submitted purchase demand plan accurate, and is there a lot of } \\
\text { rework? }\end{array}$ & $\begin{array}{l}\text { 1. Report accurately }(8) \\
\text { 2. Occasionally inaccurate }(60) \\
\text { 3. Often inaccurate }(4)\end{array}$ \\
\hline 14 & $\begin{array}{l}\text { If the demand plan requires rework, what is the reason? (Multiple } \\
\text { choice question) }\end{array}$ & $\begin{array}{l}\text { 1. Incorrect procurement method (12) } \\
\text { 2. Project parameters are not accurate } \\
(60) \\
\text { 3. Wrong procurement } \\
\text { implementation unit (4) } \\
\text { 4. Incomplete approval procedures } \\
(20)\end{array}$ \\
\hline 15 & $\begin{array}{l}\text { If it is necessary to optimize the school's centralized procurement } \\
\text { business, which aspect should be optimized? (Multiple choice } \\
\text { question) }\end{array}$ & $\begin{array}{c}\text { 1. Informatization degree (60) } \\
\text { 2. Professional degree of personnel } \\
(36) \\
\text { 3. Purchasing organization structure } \\
(20) \\
\text { 4. Not required (4) }\end{array}$ \\
\hline
\end{tabular}

It can be seen from the survey feedback results that many problems still occur in the centralized procurement process. First, the procurement cycle is too long, the procurement demand plan is inaccurate, and the emergency procurement process is not clear. Second, although the procurement implementation unit of the 
institution is basically Bidding procurement projects can be controlled within 90 days, but most of the bidding procurement projects that need to be reported to the procurement service station for more than 5 million yuan are within 90 days or even 120 days; finally, 95\% of people believe that the current hospital The school's centralized procurement business needs to be optimized, and the key parts that need to be optimized are the degree of procurement information, the degree of professionalism of personnel, and the structure of procurement organization.

\section{Optimization in the centralized procurement process of military academies}

\subsection{Start with the centralized procurement budget and carry out procurement project integration}

According to the survey, the procurement budgets submitted at the beginning of the year of the institutions include the budgets for centralized procurement projects. If it can be handed over to the procurement management department to summarize and classify the situation, merge and integrate the same items. In this way, it is possible to make an effective prediction of the annual centralized procurement project through the annual centralized procurement budget of each unit, and form an integrated centralized procurement proposal. After receiving the centralized procurement proposal issued by the procurement management department, the relevant unit of the college decides whether to merge the centralized procurement with the needs of other departments according to the needs of the unit. The procurement management department draws up the annual centralized procurement plan of the college based on the feedback from each unit, and sends it to the school procurement department for relevant pre-preparation, reducing unnecessary repetitive work in the procurement process from the source, and saving manpower and time in the procurement process cost.

\subsection{Combine centralized procurement with self- purchasing}

As mentioned above, for projects with a budget of 500,000 yuan to 1 million yuan for a single item or similar products in batches, each institution of the institution can choose to purchase on its own or hand it over to the institution's procurement organization to organize the procurement; because most procurement units do not have a major Procurement personnel of 500,000 to 1 million are basically selected to be organized by procurement agencies, which increases the workload of college procurement agencies and reduces procurement efficiency. You can contact the procurement center (office) of colleges and universities to provide business guidance and suggestions for procurement projects with a budget of 500,000 to 1 million yuan for each unit. For projects with high procurement frequency, sort out the demand standard plan and sample procurement documents for procurement. The demand unit provides reference services.

\subsection{Approval process mode of combination of series and parallel}

In the procurement process, after the procurement plan materials of each unit are prepared, they can be reported to the business division (office) of the agency and the procurement management department of the institution for review at the same time, and the opinions will be submitted to the procurement management department after the approval of the department in charge. As the process of purchasing items above the quota (over 5 million yuan) is more complicated, under the current establishment system after the military reform, the military academies and joint logistics support units are under two agencies, and it is difficult to smooth business communication channels. All colleges and universities can carry out the three processes of "Electronic Procurement Platform Reporting", "Procurement Demand Letter Reporting", and "Copy of Procurement Plan to Procurement Service Station" at the same time. There is no conflict between the three. Before the approval is issued, purchase.The service station can first meet the requirements of the procurement demand unit, and after the approval is issued, the specific procurement work can be started.

\subsection{Informatization supporting}

There is a question in the questionnaire of the previous survey: "If the school's centralized procurement business process is optimized, which aspect should be optimized", $83 \%$ of the people chose the degree of informatization. It can be seen that in the process of reengineering and optimizing the procurement management process, in order to achieve the goal of management and control, information technology must be used as the basis[4], with the help of advanced network technology to realize the rearrangement and organization of business processes to ensure that information can be Each department completes the transfer in an efficient, fast and convenient way, reduces breakpoints in the process of information transfer, and can delete non-value-added activities. In this regard, military academies need to actively build an information platform and use it as an entry point to reengineer the procurement management process.

\subsection{Focus on talent training}

The centralized procurement work is highly regulated and professional. The military academies can make full use of the opportunity to adjust the logistics system, combine with the introduction of military civilian personnel, promptly absorb talents in engineering, service, economics, law, etc., and continuously improve the procurement organization of the academy Talent team structure [5] 


\section{The effect of the optimization of the centralized procurement process of military academies}

\subsection{Effect evaluation after optimization}

Through comparative analysis of the process before and after optimization, the measures in the previous article have achieved a certain optimization effect. (1) Procurement and project approval stage. Before optimization, the procurement plan was inaccurate; the procurement approval process was too cumbersome and took too long; the procurement project was not effectively integrated. Through the integration of procurement items and the improvement of procurement information, the procurement approval process has been simplified, and the effect of improving procurement efficiency has been achieved. (2) The procurement implementation stage. Before the optimization, the procurement document preparation process was too long; the procurement related personnel were not clear enough about the procurement industry policies, regulations and related processes, and the procurement agency's suggestions for the preparation of procurement projects were increased in the early stage to improve the preparation of procurement documents and the series and parallel methods. The implementation process has been optimized; the procurement business training and other opportunities have been organized to interpret the procurement policy to each unit and explain the procurement process. (3) Related supporting facilities in the process. Before optimization, it was inconvenient to consult the procurement files; the procurement data statistics were not timely. Through the information-based procurement platform, the electronic circulation and storage of procurement materials can be realized, procurement data can be automatically generated, and the procurement situation can be grasped in real time.

\subsection{Optimized centralized procurement flowchart}

After optimizing all aspects of the centralized procurement process proposed in the previous article, the centralized procurement flowchart is as follow:

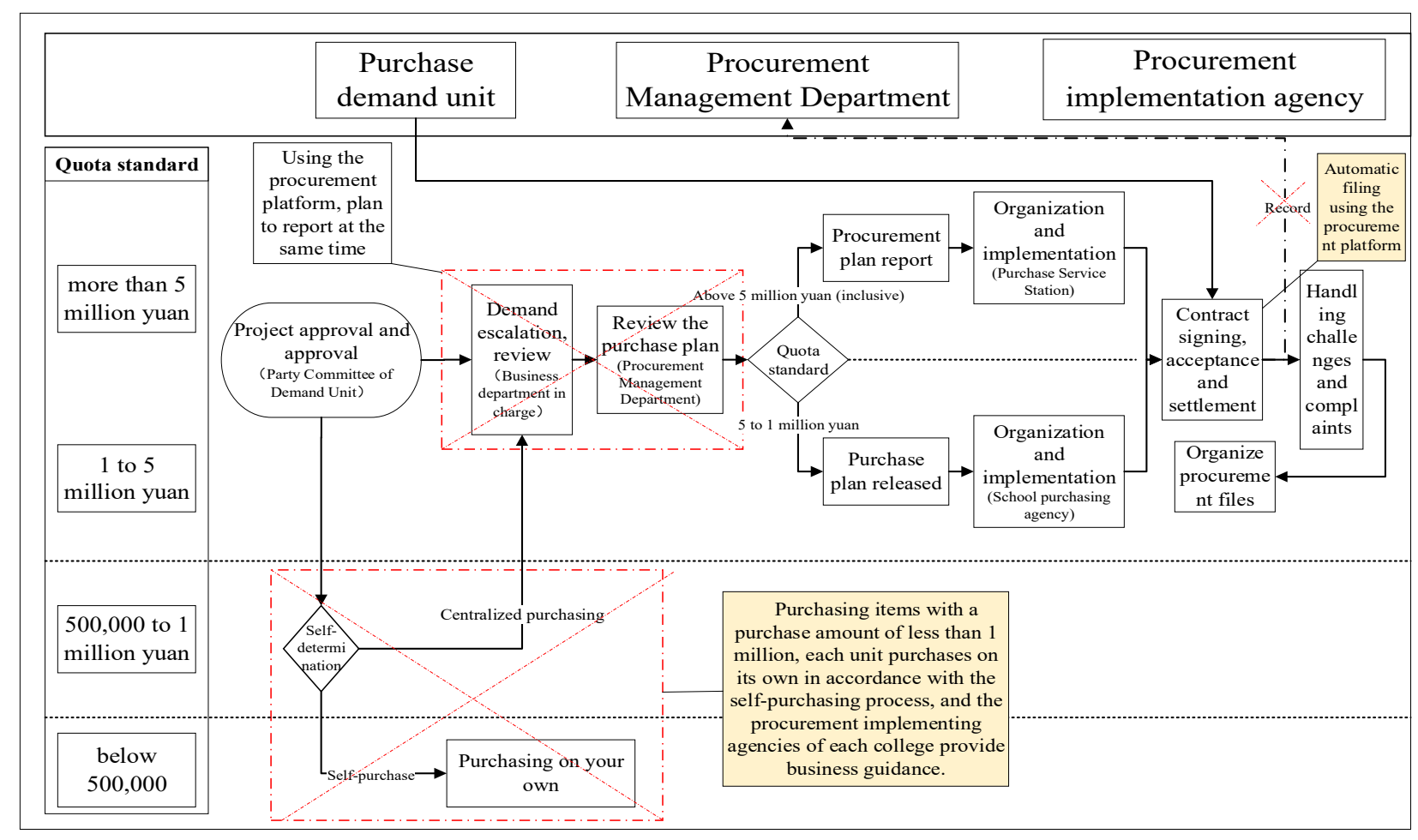

Fig 1. Purchasing flow chart after process reengineering

\section{Conclusion}

This article analyze some of the problems in the current centralized procurement workflow of military academies, such as slow procurement cycles and cumbersome procurement processes. Combined with questionnaires and other methods, corresponding measures are proposed to optimize the centralized procurement process and use the flow chart. The comparative analysis before and after has achieved the optimization effect.

\section{References}

1. Yaguang C, 2017-2018 Military Procurement Reform and Development General Report.(Military Procurement Development Report ,2018).

2. Baoyu Z,Practical exploration of advancing the formal and orderly development of sporadic 
procurement in academies(Military Procurement Development Report ,2018)

3. Maosheng $\mathrm{S}$, Research on Optimization of $\mathrm{T}$ Enterprise Procurement Process Management ( Nanjing University of Aeronautics and Astronautics, 2019)

4. Qi Y,Design and implementation of centralized procurement system for military academies (National University of Defense Technology, 2017)

5. Junxin J, Yanqin T,Improving the quality and efficiency of military academies' bidding procurement under the new situation( Chinese Government Procurement, 2019) 